\title{
NOTES ON THE GENUS CARINARIA (HETEROPODA) FROM JAPANESE AND ADJACENT WATERS
}

$\operatorname{AUTHOR}(\mathrm{S}):$

Okutani, Takashi

\section{CITATION:}

Okutani, Takashi. NOTES ON THE GENUS CARINARIA (HETEROPODA) FROM JAPANESE AND ADJACENT WATERS. PUBLICATIONS OF THE SETO MARINE BIOLOGICAL LABORATORY 1961, 9(2): 333-352

\section{ISSUE DATE:}

1961-12-20

URL:

http://hdl.handle.net/2433/175290

RIGHT: 


\title{
NOTES ON THE GENUS CARINARIA (HETEROPODA) FROM JAPANESE AND ADJACENT WATERS
}

\author{
TAKASHI OKUTANI \\ Tokai Regional Fisheries Research Laboratory, Tokyo
}

With Plates XII-XIII and 25 Text-figures

\section{Introduction}

Many taxonomic papers have been published on the genus Carinaria of Heteropoda by Smith (1888), Tesch (1906, 1949), Bonnevie (1920), and others. However, this animal group from Japanese waters has been recorded only fragmentally to this date, although a few papers have been presented about some heteropods from Japanese waters by Tokioka (1955) and Okutani (1955a, $1957 \mathrm{a}$, $1957 \mathrm{~b}, 1957 \mathrm{c}$ ).

This paper is devoted to record the occurrences of Carinarias in Japanese waters by describing the specimens found in plankton samples preserved in the Marine Resources Section of the Tokai Regional Fisheries Research Laboratory and those in the Misaki Marine Biological Station.

Thanks are due to Mr. Zinzirô NAKAI of the Tokai Regional Fisheries Research Laboratory for his encouragement and suggestions rendered to the present author during the study. Many thanks are also extended to Dr. Takasi Tokioka of the Seto Marine Biological Laboratory, Kyoto University, for his kind criticism on this work as well as careful reading of the manuscript. The writer expresses his sincere gratitude to Dr. Itirô Tomiyama, the director of the Misaki Marine Biological Station, the late Dr. Isao TAKI of the National Science Museum, Dr. John A. McGowan of the Scripps Institution of Oceanography, Dr. Masuoki Horikoshi of the Ochanomizu University, Mr. Yôji Kurata of the Tokyo Fisheries Experimental Station and Messrs. Korokurô NaKamigawa and Akibumi Teramachi of the Malacological Society of Japan for their kindness in giving the writer various facilities. Thanks are also due to the crew of the survey vessels who cooperated in collecting the most important part of the material dealt with in this study.

Publ. Seto Mar. Biol. Lab., IX (2), 1961. (Article 16) 


\section{Systematic Account}

Heteropoda: Family Carinariidae

For the convenience of becoming familiar to this animal group, the characteristics of animals of the genus Carinaria are redescribed here by summing up criteria given by previous authors.

Genus Carinaria, LAMARCK 1801, Syst. Anim., p. 98

Type species: Carinaria vitrea Làmarck (=Patella cristata LiNNÉ)

Body cylindrical in shape, translucent as it is thickly covered with translucent, gelatinous cutis throughout, proboscis thick; tail laterally compressed and usually with a tail-crest on the dorsal side, pointed at the posterior tip. Eye with triangular or cylindrical base; a pair of cephalic tentacle in front of eye, the right one frequently vestigial or absent.

Visceral nucleus on the dorsal side approximately at the middle of the entire body, apparently pedunculated, covered by a capuliform shell. Ctenidia projecting a little beyond the anterior edge of the free margin of mantle.

Musculature distinct through the cutis; muscle bands of trunk generally oblique, while those of posterior part of body and tail longitudinal, divided into several stripes on the latter. The dorsal-most muscle band of tail issues a number of delicate muscle threads radially into the crest.

Swimming fin located nearly opposite the nucleus, usually semicircular or quadrilateral in outline, with a network of regularly crossing muscle fibers; sucker without a stalk, situated on the ventro-posterior margin of fin in both sexes. Cutis generally colorless, studded with gelatinous tubercles.

Shell with a carina on the anterior margin and a number of transverse ribs on the lateral side; sperture nearly subovoid, longer than broad; larval shell helicinoid, preserved in adult.

Radular formula 2-1-C-1-2; the rhachidian tooth usually depressed trapezoid in shape, with 3 cusps at the tip; both marginals nearly equal in shape and size, sickle-shaped and pointed at the tip; lateral oblong, with a small crest and a shallow dentation on the free margin; jaw plate shield-shape, elastic.

As the specimens are easily deformed by fixation, specific characters are rather subtle excepting the shell which is, however, very frequently found destroyed. That is why a great number of species had been described under different trivial names until Tesch (1949) made a thoroughful criticism on the validity of various works prior to him and rearranged them.

In the present descriptions, the following measurement (Text-fig. 1) are given on every specimen. 
L : Entire length from the anterior tip of the proboscis extended in natural condition to the posterior tip of the tail, but excluding the tail filament.

sH : Shell height; the heighest part of the shell standing on the aperture; the height of the nucleus is measured in place of $\mathrm{sH}$ when the shell is lost.

SD : The major diameter of the shell aperture.

tL : Tail length from the posterior margin of the base of the swimming fin to the posterior tip of the tail.

tH : Tail height from the ventral side to the crest margin at the highest part of the dorsal crest.

In addition, body height, length of the eye including both the lens and basal part, eye diameter and ratios between these measurements are occasionally taken into consideration.

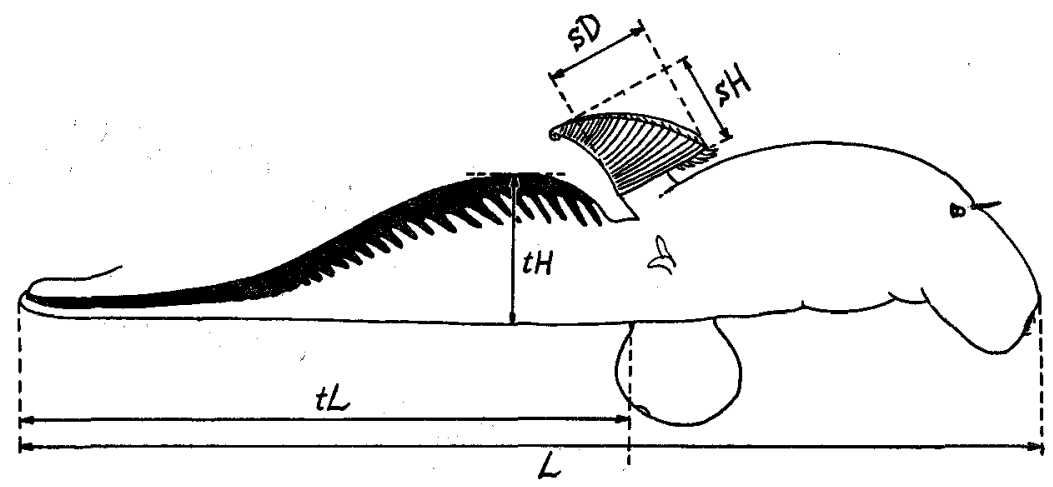

Text-figure 1. Diagram showing various measurements referred. L: entire length, $\mathrm{sH}$ : shell height, $\mathrm{sD}$ : major diameter of the aperture, tL : tail length, tH: tail height.

\section{Carinaria cristata (LINNÉ, 1766)}

(Text-figs. 2-8; Pl. XII, figs. 1-4; Pl. XIII, fig. 1)

Carinaria vitrea, REEVE, 1865, vol. xv, pl. 1, figs. 2a-b;

Carinaria cristata, E. A. SMITH, 1888, p. 30, figs. 3a-b, 4a-b ;

Carinaria cristata, Tesch, 1906, p. 65, pl. 9, figs. 35-42; pl 10, fig. 43;

Carinaria cristata, THIELE, 1929, p. 257 ;

Carinaria cristata, TESCH, 1949 , p. 28, pl. 2, figs. 3A-D ;

Carinaria cristata, TокıоKA, 1951, p. 1134, fig. 3223 ;

Carinaria cristata, TAKI, 1954, pl. 129, fig. 1.

Body attains more than $500 \mathrm{~mm}$ in entire length (L); dorsum of the trunk conspicuosly elevated, height reaching $16 \%$ to $\mathrm{L}$ in adult; tail-crest semi-circular in outline, tH generally $20-26 \%$ to $\mathrm{tL}$, and with the dorsal margin sharply edged 
(Text-fig. 5) ; the posterior part of the crest is gently sloping down posteriorly and tapering to a whip-like prolongation with a nearly triangle cross-section; a dark-colored short filament follows the prolongation, $30 \mathrm{~mm}$ in length in a $240 \mathrm{~mm}$ long specimen.

Eye relatively small, dark in color, with the triangular retinal part broadlybased; a pair of cephalic tentacle in from of eyes, sometimes hidden in the

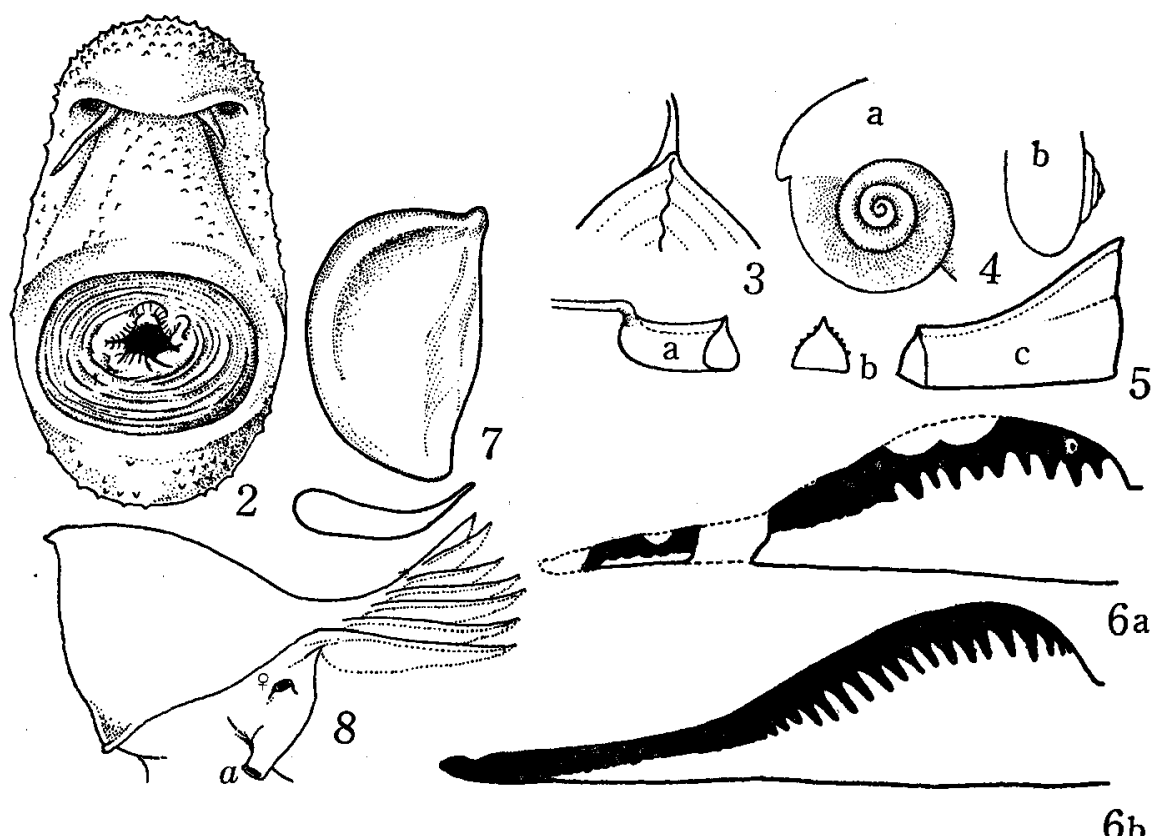

Text-figures 2-8. Carinaria cristata (LINNÉ)

2. Frontal view, showing the cephalic tentacles of different length; $388 \mathrm{~mm}$ long specimen from Koajiro Cove, Sagami Bay.

3. Carina of shell, apertural view; $501 \mathrm{~mm}$ long individual from Sagami Bay.

4. Protoconch, $1.15 \times 0.9 \mathrm{~mm}$; from Tosa Bay, $\mathrm{sH}=22.6 \mathrm{~mm}$.

5. Diagram showing the shape of the posterior part of tail.

6. Two types of color-pattern of tail; a. $210 \mathrm{~mm}$ long injured specimen; b. $340 \mathrm{~mm}$ long injured individual.

7. Jaw plate of a full-grown specimen.

8. Anus and genital opening of the $430 \mathrm{~mm}$ long injured female from Misaki. a : anus, o : genital opening.

transverse groove frequently observed on the brow of full-grown specimens, right one sometimes smaller than the left (Text-fig. 2), for example, right $6 \mathrm{~mm}$ and left $16 \mathrm{~mm}$ in a $340 \mathrm{~mm}$-specimen.

Shell highly elevated, curved backwards; $\mathrm{sH}$ about $80 \%$ to $\mathrm{sD}$; carina about $7 \%$ as wide as $\mathrm{sD}$, consisting of two lamellae spaced by an extremely narrow slit and slightly inclined to the right side (Text-fig. 3). 
Cutis covered with many variously sized gelatinous tubercles all over the surface, most densely on the dorsum, but rather sparsely on the ventral side. The body usually milky white in young specimens, but often faintly purplish on the dorsal side; the dorsal half of the tail-crest dark reddish purple or burgundy, but usually sprinkled with white spots formed by large-sized mamillar tubercles; the ventral margin of this colored area is asymmetrically undulating (Text-fig. 6).

Table 1. Data of examined C. cristata (L.).

\begin{tabular}{|c|c|c|c|c|c|c|c|c|}
\hline \multicolumn{3}{|c|}{ Locality } & \multirow{2}{*}{ Date } & \multirow{2}{*}{ Sex } & \multirow{2}{*}{$\underset{(\mathbf{m m})}{\mathrm{L}}$} & \multirow{2}{*}{$\underset{(\mathrm{mm})}{\mathrm{sH}}$} & \multirow{2}{*}{$\mathrm{sH} / \mathrm{sD}$} & \multirow{2}{*}{$\mathrm{tH} / \mathrm{tI}$} \\
\hline Lat. $\mathrm{N}$ & Long. E & & & & & & & \\
\hline Koajiro & Cove, Miura Peninsula & (Misaki MBS) & Aug. 26, '36 & 우 & $430^{*}$ & - & - & 0.18 \\
\hline Koajiro & Cove, Miura Peninsula & $(\quad n)$ & $\eta$ & $0^{7}$ & 388 & - & - & 0.36 \\
\hline Neighbo & Jurhood of Misaki MBS & $"$ & - & $\sigma^{3}$ & 500 & - & - & 0.26 \\
\hline Araiham & na Beach, Miura Peninsula & ( & Jan., '56 & 우 & $160^{*}$ & - & - & - \\
\hline Moroiso & Cove, Miura Peninsula & (Mr. HAMASAKI) & Dec. $23, ' 57$ & ㅇ & $340^{*}$ & - & - & 0.26 \\
\hline Maeham & na Beach, Niijina Isl. & (Mr, KURATA) & Mar. 8, '58 & 우 & $340^{*}$ & - & 一 & - \\
\hline Moroiso & Cove, Miura Peninsula & (Dr. HoRIKOSHI) & Oct. $12, ' 58$ & 우 & 210 & - & - & - \\
\hline Najima, & Sagami Bay & (Misaki MBS) & Mar., '59 & 9 & 501 & 56 & 0.82 & 0.20 \\
\hline Kasajim & a, Sagami Bay & (Mr. NAKAMIGAWA) & May $11, ' 59$ & $\sigma^{7}$ & 240 & 35 & 0.95 & 0.33 \\
\hline Tôshiki & Beach, Ôshima Is1. & (Mr. KuRATA) & July $26, ' 61$ & - & $140^{*}$ & 一 & - & - \\
\hline Off Nom & ashi, Ôshima Isl. & (Mr. KuRATA) & Apr. 24, '61 & - & $58^{*}$ & - & - & - \\
\hline Tosa $\mathrm{Ba}$ & & (Mr. TeramachI) & - & - & - & 22.6 & 0.77 & - \\
\hline $35^{\circ} 07.2$ & $139^{\circ} 34.2$ (Sôyô St. U3) & & Dec. $7, ' 59$ & 우 & - & - & - & - \\
\hline $34^{\circ} 06.7$ & $136^{\circ} 51.8$ (Sôyô St. 135) & & Feb. $24, ' 61$ & 우 & 68 & 13.0 & 1.00 & 0.47 \\
\hline
\end{tabular}

* Astrisk show the specimen measured in somewhat injured state.

\section{Carinaria lamarcki (PÉRON et LESUEUR, 1810)}

(Text-fig. 9, 10 and 12 ; PI. XIII, figs. 3,6)

Carinaria fragilis, REEvE, 1865, vol. xv, pl. 1, figs. 1a-b ;

Carinaria lamarckii E. A. SмITH, 1888, p. 32 ;

Carinaria cymbium, WOODWARD, 1890, p. 202, fig. 66 ;

Carinaria australis, VAYssiëre, 1904, p. 22, pl. 1, figs. 11-16 ;

Carinaria mediterranea, VAYSSIÈRE, 1904, p. 11, pl. 1, figs. 1-10; pl. 2, fig. 17 ;

Carinaria mediterranea, PELSENEER, 1906, p. 162, fig. 142 ;

Carinaria mediterranea var. oceanica, VAYSSIÈRE, 1904, p. 17, pl. 4, figs. 51-53;

Carinaria lamarcki, BONNEVIE, 1920, p. 6 ;

Carinaria lamarcki, TESCH, 1949, p. 26, pl. 1, fig. 1.

The largest specimen in the present material measured only $30 \mathrm{~mm}$ in $\mathrm{L}$, although TEsch (1949) stated that specimens from the Mediterranean Sea attained $220 \mathrm{~mm}$; tail-crest abruptly increases the height at the proximal one third (Text- 
fig. 12), not so rounded in outline as in the forgoing species, and without any distal prolongation; $\mathrm{tH} 25 \%$ to $\mathrm{tL}$. Cephalic tentacles long, the right one longer than the left. Shell much depressed, apex conspicuously involute, sH 50\% to sD in fully grown specimen (after Reeve, 1865). Cutis covered sparsely with large tubercles all over the surface.

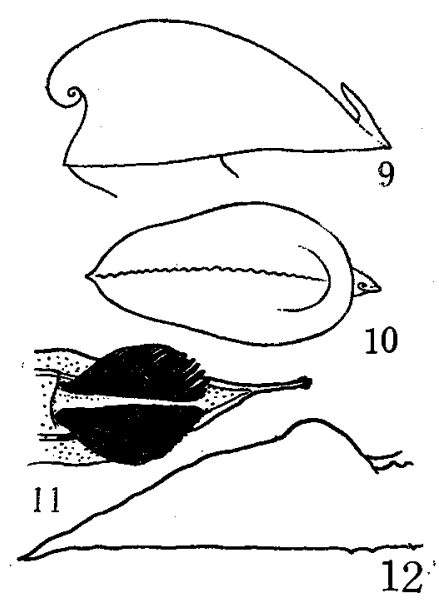

Text-figures 9, 10, 12. Carinaria lamarcki PÉron et LESUEUR

9. Outline of visceral nucleus; a specimen from Naples, preserved in Tokyo University.

10. Apertural view of a full-grown shell (after REEvE, 1865).

12. Tail; a $25 \mathrm{~mm}$ long individual from the station $30^{\circ} 38^{\prime} .9 \mathrm{~N}$, $131^{\circ} 23^{\prime} .8 \mathrm{E}$.

Text-figure 11. Carinaria lamarcki challengeri BoNNEvIE, ventral view of the "clasper"; a $15 \mathrm{~mm}$ long specimen from the station $34^{\circ} 18^{\prime} \mathrm{N}, 140^{\circ} 56^{\prime} \mathrm{E}$.

Table 2. Data of examined C. lamarcki (PÉRON et LESUEUR).

\begin{tabular}{|c|c|c|c|c|c|c|c|c|c|}
\hline \multicolumn{3}{|c|}{ Locality } & \multirow{2}{*}{ Date } & \multirow{2}{*}{ Time } & \multirow{2}{*}{$\begin{array}{l}\text { Layer } \\
\text { (m) }\end{array}$} & \multirow{2}{*}{ Sex } & \multirow{2}{*}{$\underset{(\mathrm{mm})}{\mathbf{L}}$} & \multirow{2}{*}{$\underset{(\mathrm{mm})}{\mathrm{sH}}$} & \multirow{2}{*}{$\mathrm{tH} / \mathrm{tL}$} \\
\hline Lat. $\mathrm{N}$ & Long. $\mathrm{E}$ & & & & & & & & \\
\hline $30^{\circ} 38.9$ & $131^{\circ} 23.8$ & (Sôyô St. 70) & Feb. $18, ' 52$ & 1839 & 0 & 우 & 25 & - & 0.20 \\
\hline $43^{\circ} 00.0$ & $160^{\circ} 00.0$ & (Tenyô St. F1) & Aug. $3,^{\prime} 55$ & 0715 & $0-25$ & - & 19 & - & 0.23 \\
\hline $32^{\circ} 11.5$ & $139^{\circ} 51.0$ & (Sôyô St. 25) & Jun. $28, ' 56$ & 0000 & $0-150$ & - & 6.6 & - & - \\
\hline $32^{\circ} 46.3$ & $133^{\circ} 08.8$ & (Sôyô St. 32) & Feb. $10, ' 57$ & 2107 & 0 & 一 & 30 & 3 & 0.40 \\
\hline Isl. $\mathrm{Hac}$ & chijô $\quad(\mathrm{Mr}$ & (KuRAta) & Mar. 17, '55 & - & 0 & - & - & - & - \\
\hline
\end{tabular}

3. Carinaria lamarcki challengeri BONNEVIE, 1920

(Text-fig. 11; Pl. XIII, fig. 8) 
Carinaria lamarcki (part?) E. A. SмITH, 1888, p. 37;

Carinaria poseudo-rugosa (part) VAYASSIÈRE, 1904, p. 20, pl. 6, figs. 82-5;

Carinaria lamarcki var. challengeri BonNEvIE, 1920, p. 6, pl. 2, figs. 16-25.

Body up to $15 \mathrm{~mm}$ in $\mathrm{L}$; dorsum remarkably elevated; tail-crest much depressed; eye small; left cephalic tentacle long but hidden in the transverse groove on the brow, the right one absent; a dark colored appendage-clasper by BonNEvie (1920) - on the ventral side of tail (Text-fig. 11); cutis wholly punctate.

Table 3. Data of examined C. lamarcki challengeri BonNEviE.

\begin{tabular}{|c|c|c|c|c|c|c|c|c|c|}
\hline \multicolumn{3}{|c|}{ Locality } & \multirow{2}{*}{ Date } & \multirow{2}{*}{ Time } & \multirow{2}{*}{$\begin{array}{l}\text { Layer } \\
(\mathrm{m})\end{array}$} & \multirow{2}{*}{ Sex } & \multirow{2}{*}{$\underset{(\mathrm{mm})}{\mathrm{L}}$} & \multirow{2}{*}{$\mathrm{sH}$} & \multirow{2}{*}{$\mathrm{tH} / \mathrm{tL}$} \\
\hline Sat. N & Long. $\mathrm{E}$ & . & & & & & & & \\
\hline $34^{\circ} 18.0$ & $140^{\circ} 56.0$ & (Meiyô St. C53) & Mar. $26, ' 58$ & 1730 & 0 & 우 & 15 & - & - \\
\hline $32^{\circ} 23.0$ & $135^{\circ} 51.0$ & (No. 2 Kuroshio St. 6) & Dec. $8,{ }^{\prime} 59$ & 1750 & 0 & $\sigma^{2}$ & 15 & - & - \\
\hline $33^{\circ} 08.0$ & $140^{\circ} 00.0$ & (Sôyô St. B3) & Mar. $3,{ }^{\prime} 60$ & 2142 & 0 & $q$ & 11 & - & - \\
\hline \multicolumn{3}{|c|}{ The Sea off Enshu-Nada } & - & - & 0 & 우 & 20 & - & - \\
\hline
\end{tabular}

Remarks: Various forms of C. lamarcki (PÉRON et LESUEUR) has been described from different localities of the world seas. Especially, BonNevie (1920) described a well-defined small form trom Gibralter and African waters which is only 30 $40 \mathrm{~mm}$ in entire length. Although her specimens were at first considered to be a juvenile of a known species, she showed by histological examination that the gonads of the specimens were already matured. Moreover, the specimens were distantly characterized by having the "clasper" consisting of a pair of darkly pigmented folds on the postero-ventral side of the body. This organ is not found on any other forms including the typical lamarcki in the present material. No comprehensive works have been made on this "clasper" until to-day, but it is very interesting to state here that the similar black organ is observed on other Carinarid animal, Cardiopoda richardi (VAYSSIÈRE).

\section{Carinaria (cristata var.?) japonica OKUTANI, 1955}

(Text-figs. 13-16; Pl. XIII ; figs. 2, 7)

Carinaria lamarcki, Dales 1952, p. 1110, fig. 4 (non PÉron et Lesueur);

Carinaria japonica, OKUTANI 1955, p. 251, figs. 1-3.

Body attains $62 \mathrm{~mm}$ in $\mathrm{L}$; tail-crest conspicuously elevated nearly to the level of the tip of the nucleus, triangle in outline, tH $43-53 \%$ to tL; eye with the broardly based and traianglar retinal part (Text-fig. 14); the right cephalic tentacle slightly shorter than the left, although both tentacles may often be of equal length.

Shell moderately elevated, sH $80-100 \%$ to sD; nuclear whorl coils 4 times and marked with very fine striae on the surface, umbilicus very narrow, faintly 
yellow; post-nuclear parts translucent, width of carina $15 \%$ to sD (Text-figs. $15,16)$. Cutis smooth with several gelatinous tubercles on the ventrolateral area of trunk.

Rhachidian depressed trapezoid in shape, with 3 very slender acute cusps on the tip; laterals oblong and with a sharp crest on the free margin; 2 marginals sickle shaped sharply pointed at the tip; on a $34 \mathrm{~mm}$-long specimen rachidian 0.75 $\mathrm{mm}$ in width, lateral $0.45 \mathrm{~mm}$ long and $0.15 \mathrm{~mm}$ wide, marginal $0.50 \mathrm{~mm}$ in length.

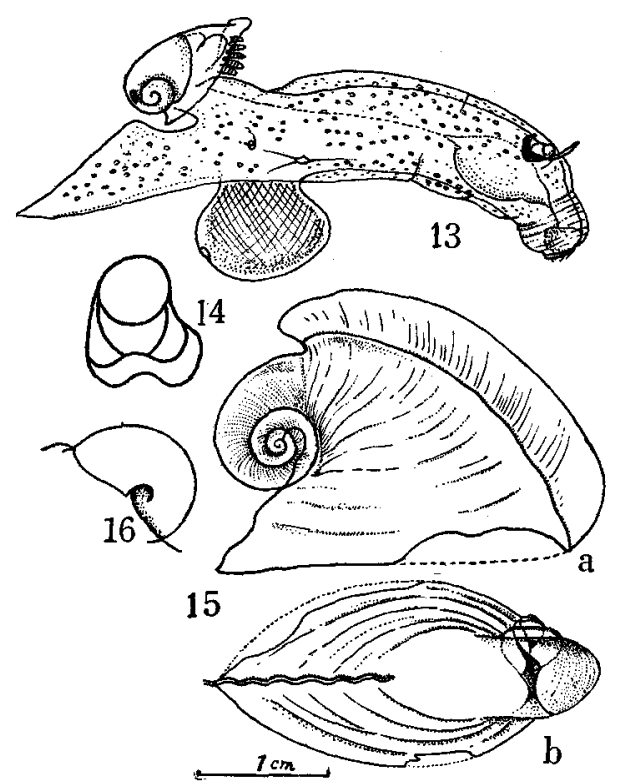

Text-figures 13-16. Carinaria (cristata var. ?) japonica OKUTANI.

13. A $14.5 \mathrm{~mm}$ long individual from the station $43^{\circ} \mathrm{N}, 179^{\circ} \mathrm{E}$.

14. Eye of the same specimen, dorsal view.

15. Shell of an individual from the station $43^{\circ} 02 \mathrm{~N}, 176^{\circ} \mathrm{E}$; $\mathrm{sH}=2.0 \mathrm{~mm}$.

16. Umibilicus of the same shell.

Table 4. Data of examined C. japonica OKUTANI.

\begin{tabular}{|c|c|c|c|c|c|c|c|c|c|c|}
\hline \multicolumn{3}{|c|}{ Locality } & \multirow{2}{*}{ Date } & \multirow{2}{*}{ Time } & \multirow{2}{*}{$\begin{array}{c}\text { Layer } \\
\text { (m) }\end{array}$} & \multirow{2}{*}{ Sex } & \multirow{2}{*}{$\stackrel{\mathrm{L}}{(\mathrm{mm})}$} & \multirow{2}{*}{$\underset{(\mathrm{mm})}{\mathrm{sH}}$} & \multirow{2}{*}{$\mathrm{sH} / \mathrm{sD}$} & \multirow{2}{*}{$\mathrm{tH} / \mathrm{tL}$} \\
\hline Lat. N & Long. E & & & & & & & & & \\
\hline $44^{\circ} 11.0$ & $159^{\circ} 30.0$ & (Kôyô St. 20) & Aug. $7, ' 54$ & 0820 & 0 & - & 19 & - & - & - \\
\hline$* 36^{\circ} 21.0$ & $141^{\circ} 00.0$ & (Heiwa-Ibaraki St. 5) & Jun. $29, ' 55$ & 1340 & $0-150$ & q & 62 & 一 & - & 0.43 \\
\hline $43^{\circ} 48.0$ & $164^{\circ} 38.5$ & (Sôyô St. 38) & Sep. $6,,^{\prime} 58$ & 1827 & 50 & 우 & 28 & 4.5 & 1.12 & 0.43 \\
\hline $41^{\circ} 00.0$ & $175^{\circ} 00(W)$ & )(Sôyô St. 25’) & Aug. 21, '58 & 1840 & $0-150$ & q & 62 & 6.5 & 0.93 & 0.51 \\
\hline Off Kinl & kazan ( $\mathrm{T}$ & Cokiwa St. 14) & Jul. $24, ' 59$ & 1005 & 0 & 우 & 60 & - & - & - \\
\hline
\end{tabular}

* Holotype, stored in the Tokai Reg. Fisher. Res. Lab., Tokyo. 
Besides the specimens shown in the above table, a great number of specimens of various stages were collected at some of the serial stations along the latitude of $43^{\circ} \mathrm{N}$, the data of which is given in Chapter $\mathrm{V}$ where the distribution of the genus is discussed.

\section{Carinaria galea BENSON, 1835}

(Text-figs. 17, 18 ; Pl. XIV, figs. 4, 5)

Carinaria galea E. A. SмITH, 1888, p. 35 ;

Carinaria galea TESCH 1906, p. 71 , pl. 10, figs. 44,45 ;

Carinaria galea TESCH 1949, p. 27, pl. 1, figs. 2 .

Body attains $42 \mathrm{~mm}$ in L, rather slender; tail short, tail-crest much depressed, tH $60 \%$ to $\mathrm{tL}$; cutis quite transparent, furnished with large gelatinous tubercles distributed sparcely all over the surface. Eye darkly colored, retinal part with narrow base (Text-fig. 18); right tentacle vestigial.

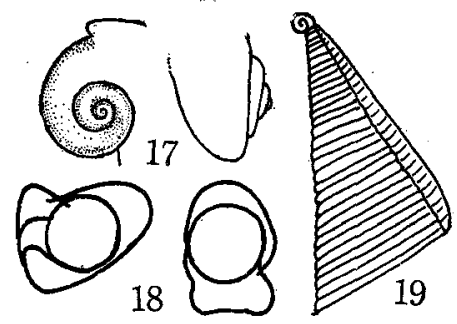

Text-figures 17, 18. Carinaria galea BENSON.

17. Protoconch of an Individual from Tosa

Bay, $1.3 \times 1.2 \mathrm{~mm} ; \mathrm{sH}=13.2 \mathrm{~mm}$.

18. Eye of the same specimen.

Text-figure 19. Carinaria cithara BENSoN, shell (after TESCH, 1949).

Shell elevatrd, curved backward, sH larger than sD; carina enormously high, its width attaining nearly $25 \%$ to $\mathrm{SD}$; protoconch slightly inclinated (Text-fig. 17).

Table 5. Data of examined C. galea BENSoN.

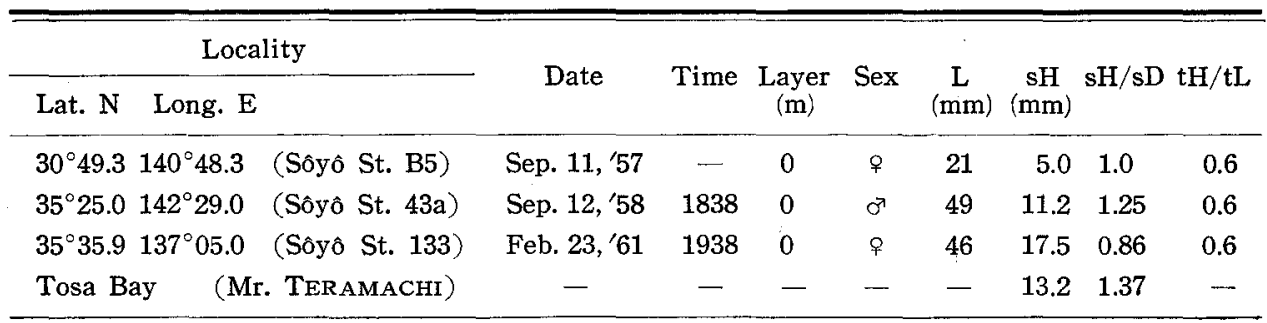




\section{Other species hitherto known but not found in the present material}

Carinaria cithara Benson, 1835.

Carinaria cithara procumbens TESCH, 1949.

The above-mentioned two forms were not found in the present material as they are likely to be distributed in the tropical waters. These forms are small ones attaining only $50 \mathrm{~mm}$ in $\mathrm{L}$ at the maximum and distinctly characterized ay thair much elevated shell with sH about two times SD (Tesch, 1949). Tesch's extremely rare subspecies, procumbens is differentiated from the typical form in having the shell bending anteriorly; this feature is quite unique as the shell is generally curved backward in other forms of the genus.

\section{Interspecific Relationship}

Species of the genus Carinaria are considered to be divided into two groups characterized by structures of eye and protoconch, which might deserve to be treated as subgenera. One of them comprises cristata, lamarcki, japonica and galea posessing each the triangular retinal part and nearly smoothly surfaced protoconch. The other is represented by a single species, cithara, with cylindrical eyes and protoconch ornamented with apiral lines on the surface.

Juvenile specimens of three species, cristata, japonica and lamarcki are hardly distinguished from each other because of close morphological resembalance in details. In this respect, Tesch $(1949$, p. 26) stated, "it is not always possible to identify a mass of such small Carinariae with absolute certainty, when, as is frequently the case, the shell is absent; and only an experienced eye can tell specific differences which are hardly fit to be put in words." However, young specimens of lamarcki seem to have retinal parts proportionally broarder than in juveniles of japonica in the same body length as is show below:

\begin{tabular}{|c|c|c|c|}
\hline & $\mathrm{L}$ & $\begin{array}{l}\text { Length of eye } \\
\text { including retina }\end{array}$ & $\begin{array}{l}\text { Diameter of } \\
\text { retina }\end{array}$ \\
\hline lamarcki & $25 \mathrm{~mm}$ & $0.63 \mathrm{~mm}$ & $1.08 \mathrm{~mm}$ \\
\hline japonica & 26 & 0.63 & 0.63 \\
\hline lamarcki & 11 & 0.55 & 1.00 \\
\hline japonica & 9 & 0.47 & 0.47 \\
\hline
\end{tabular}

Furthermore, it is noteworthy that juveniles of cristata resemble strikingly those of japonica, although the former can be distinguished by the existence of dorsal tubercles even in immature states and by low and more rounded dorsalcrest as TESCH already showed (1949, p. $25 \&$ pl. 2, fig. 3C). The ratio between $\mathrm{sH}$ and $\mathrm{sD}$ may be useful to identify immature specimens of these two species. As none of the immature specimens of cristata was found in the present material, 
the ratio was estimated here on the measurements made by retracing growth lines on the mature shell.

$\begin{array}{llll} & \mathrm{sD} & \mathrm{sH} & \mathrm{sD} / \mathrm{sH} \\ \text { cristata } & 2.6 \mathrm{~mm} & 2.6 \mathrm{~mm} & 1.00 \\ \text { japonica } & 2.6 & 1.7 & 0.65\end{array}$

Morphological similarities between juvenile cristata and japonica seem to suggest that the latter might be a local form of the former confined to the northern Pacific.*

Adults of species of the genus, Carinaria are easily distinguished by the characters shown below.

Table 6. Shell characters of five species of Carinaria.

\begin{tabular}{|c|c|c|c|c|}
\hline & General appearance & Protoconch & $\mathrm{sH}(\max )$. & $\mathrm{sH} / \mathrm{sD}$ \\
\hline cristata & Elevated, top curves backwards. & $\begin{array}{l}\text { Helicinoid, faintly } \\
\text { yellowish }\end{array}$ & $56 \mathrm{~mm}$ & $0.7-0.8$ \\
\hline lamarcki & Depressed, top conspicucusly involutes. & Helicinoid & 41 & 0.5 \\
\hline japonica & Elevated, top curves backwards. & $\begin{array}{l}\text { Helicinoid, with fine } \\
\text { growth striae }\end{array}$ & 6.5 & $0.8-1.0$ \\
\hline galea & $\begin{array}{l}\text { Elevated, top curves backwards, carina } \\
\text { very high. }\end{array}$ & Helicinoid, inclinated & 13.2 & $1.0-1.4$ \\
\hline cithara & $\begin{array}{l}\text { Highly erected; in procumbens anterior } \\
\text { edge concave. }\end{array}$ & $\begin{array}{l}\text { Situating at the top, } \\
\text { with spiral lines. }\end{array}$ & 11 & 2.0 \\
\hline
\end{tabular}

Table 7. Characters of soft body parts of five species of Carinaria.

\begin{tabular}{|c|c|c|c|c|c|}
\hline & Eye & & Dorsal-crest & $L(\max )$. & Tubercles \\
\hline cristata & $\begin{array}{l}\text { Triangular, } \\
\text { broad base }\end{array}$ & with & $\begin{array}{l}\text { Semi-circular; with taper. } \\
\text { ing whip-like prolonga- } \\
\text { tion at the end. }\end{array}$ & $500 \mathrm{~mm}$ & $\begin{array}{l}\text { Very densely on the } \\
\text { whole surface }\end{array}$ \\
\hline lamarcki & & ” & Depressed & $220^{* *}$ & $\begin{array}{l}\text { Large, on the whorl } \\
\text { surface }\end{array}$ \\
\hline $\begin{array}{l}\text { lamarcki } \\
\text { challengeri }\end{array}$ & & $"$ & Much depressed & 30 & Inconspicuous \\
\hline japonica & & $"$ & Elevated, triangular & 62 & $\begin{array}{l}\text { Only on the ventro. } \\
\text { lateral part }\end{array}$ \\
\hline galea & $\begin{array}{l}\text { Triangular, } \\
\text { narrow base }\end{array}$ & $e^{\text {with }}$ & Not prominent & 49 & $\begin{array}{l}\text { Sparsely on the whole } \\
\text { surface }\end{array}$ \\
\hline citbara & Cylindrical & & Not prominent & 50 & Sparsely \\
\hline
\end{tabular}

* Although the Mediterranean forms may grow up such a large size (TEsch 1949, p. 27), the Indo-Pacific specimens are always as small as shown in the present material. This reveals that at least two local forms are differentiated in this species.

** In this respect, Dr. T. TokIokA thinks that japonica may be a form of lamarcki rather than that of cristata. For this reason he points out that japonica may differ from cristata in shape of tail and proportion of tail and trunk as well as in feature of carina (personal communication). 


\section{Distributional Account}

1. Geographical distribution, with special reference to the occurrence of C. japonica in the eastern waters off Japan.

Heteropods are the inhabitants of the warm waters of the world; all the species are known from the Indo-Pacific, but some are lacking in the Atlantic as the following table given by Tesch (1949, p. 49) shows clearly.

Table 8. Distribution of Carinaria in the world seas (modified from TESCH 1949).

\begin{tabular}{lccccc}
\hline & Atlantic Ocean & Indian Ocean & \multicolumn{2}{c}{ Pacific Ocean } & Mediterranean \\
\cline { 3 - 6 } & & & Tropical & Temperate & \\
\hline cristata & - & $\times$ & $\times$ & $\times$ & - \\
lamarcki & $\times$ & $\times$ & $\times$ & $\times$ & $\times$ \\
lamarcki challengeri & $\times$ & $\times$ & $?$ & $\times$ & $\times$ \\
japonica & - & - & - & $\times$ & - \\
galea & - & $\times$ & $\times$ & $\times$ & - \\
cithara & - & $\times$ & $\times$ & - & - \\
\hline
\end{tabular}

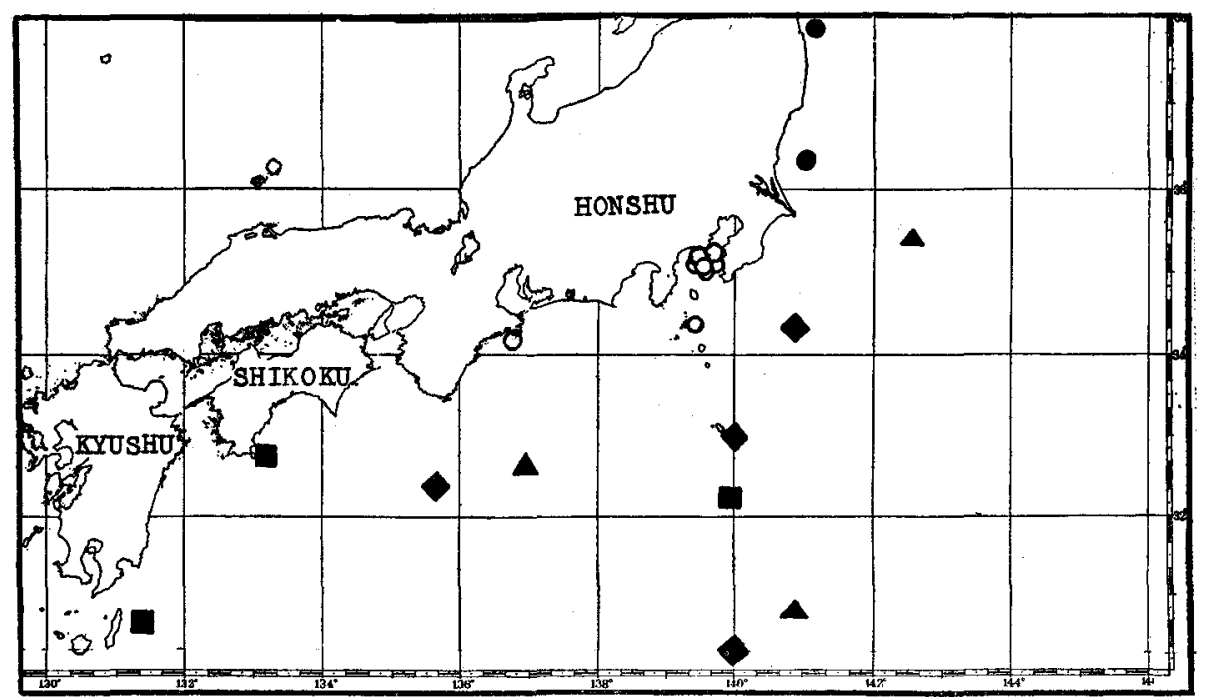

Text-figure 20. Distributional map of Carinarian species in Japanese waters.

$\circ:$ C. cristata, $:$ : C. lamarcki, $\square:$ C. lamarcki challengeri $\bullet:$ C. japonica, $4:$ C. galea.

Generally speaking, in the Pacific, neither peculiar specific distributions nor peculiar distributional areas are conceivable, although some species show the trend to the tropical region and quite unseen in Japanese waters. In Japanese water Carinariae are usually collected in the Kuroshio area, sometimes by 
plankton-net or found stranded. As is shown in text-figure 20, the stations of occurrence are found along the Kuroshio or in the area generally with surface water temperature of $20^{\circ} \mathrm{C}$ or thereabout. Carinaria may sometimes be found accumulated in a great number together with other plankters along the boundary between different waters, as is seen along the polar-front of the Kuroshio.

For instance, a considerable number of Carinaria were collectedby the R. V. Tenyo-Maru during her cruise in the summer 1955. They were collected at or near the serial stations along the latitude of $43^{\circ} \mathrm{N}$. Although most of them were very young and some were coiled, they were identified as $C$. japonica after the close comparative studies arranging the specimens in the order of the size. And this cleared a part of the early larval stages of this species as is mentioned later in this paper.

According to OKUTANI (1957 b), the lowest water temperature estimated for the occurrence of Atlanta (probably lesueuri) was $160^{\circ} \mathrm{C}$. And some workers

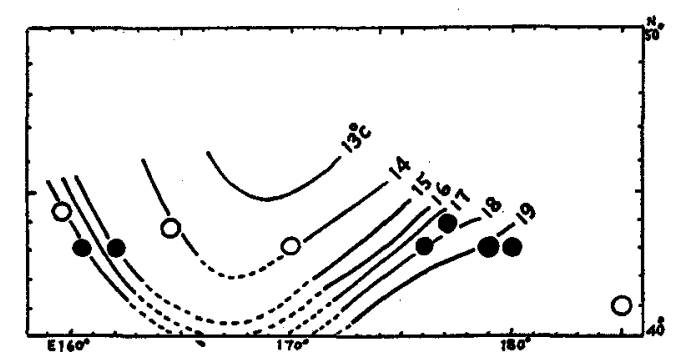

Text-figure 21. Occurrence of Carinaria japonica in the polar front area of the Kuroshio; solid circle shows the station where this species was collected in 1955; open circles shows that in other years; isotherms are for the summer 1955.

seem to consider that no heteropods inhabit in the northern part of the North Pacific. However, the oceanographic data of the R. V. Tenyô-Maru in the summer 1955 lowered the lower critical water temperature for the occurrence of Carinaria to $15^{\circ} \mathrm{C}$ or even below it. (Text-fig. 21 ).

In this polar front area of the Kuroshio are freqently met with other large sized plankton such as Janthina, Velella etc. which are always found in a fullgrown stage. This seems to show that these animals are bred in the more southern warm water area and drifted to there by the current. On the contrary, C. japonica is considered to be propagating in the area surveyed by the Teny $\hat{o}-$ Maru, as very early stages were found there in quantity. Anyhow it is evident that this species is distributed more northerly in the colder water than any other species of the genus. This seems to be supported by Dales (1952) who found a plenty of specimens probably belonging to this form from Californian waters where other heteropods were relatively scarce. 
2. Possible diurnal vertical migration.

As has been cleared by the present author (1957 a, $1957 \mathrm{~b}$ ), pteropodan and heteropodan faunas on the sea surface are completely changed by sun-set and sun-rise. Most of the specimens collected by the plankton net with a $130 \mathrm{~cm}$ diameter were fished by surface towing, and only two in the present material were collected at $25 \mathrm{~m}$ and another at $50 \mathrm{~m}$ layer by mid-layer horizontal haul. However, as the majority of them were got at night (from 18.00 to 06.00 ) and some Pterotracheas are known from the mid-layer between 256 and $600 \mathrm{~m}$ deep in daytime (OKutani, $1957 \mathrm{c}$ ), it is very possible that Carinarias do the diurnal vertical movement to some extent.

Table 9. Data of $C$. japonica from the polar-front area of the Kuroshio in the summer 1955.

\begin{tabular}{|c|c|c|c|c|c|c|c|c|c|}
\hline $\begin{array}{l}\text { St. } \\
\text { No. }\end{array}$ & Lat. N & Long. $E$ & Date ( & 1955) & Time & $\begin{array}{c}\text { Layer } \\
(\mathrm{m})\end{array}$ & $\begin{array}{l}\text { Num. } \\
\text { Spec. }\end{array}$ & $\underset{\text { rátio }}{\text { Sex }}$ & $\begin{array}{c}\mathrm{L} \text { (range) } \\
\text { in } \mathrm{mm}\end{array}$ \\
\hline 12 & $43^{\circ} 00$ & $160^{\circ} 01.5$ & Aug. & & $0135-40$ & 0 & 5 & $?$ & $17-20$ \\
\hline 13 & $43^{\circ} 00$ & $162^{\circ} 00$ & $"$ & 3 & 0813-18 & 0 & 18 & 우 15 , 오 3 & $\begin{array}{l}12-44(\text { sH } 5.5-5.6 \\
\quad \text { for } \mathrm{L} 35-37)\end{array}$ \\
\hline 20 & $43^{\circ} 02$ & $176^{\circ} 00$ & $"$ & 6 & 2254 & $0-150$ & 2 & $?$ & $2.8,3.0$ \\
\hline 20 & $43^{\circ} 02$ & $176^{\circ} 00$ & $"$ & $"$ & $0020-25$ & 0 & ca. 1000 & $?$ & $1.2 \times 1.9-0.6 \times 1.0^{*}$ \\
\hline $21 \mathrm{a}$ & $43^{\circ} 00$ & $179^{\circ} 00$ & $"$ & 7 & $1620-25$ & 0 & $\left\{\begin{array}{r}60 \\
1\end{array}\right.$ & $\begin{array}{l}? \\
\sigma^{3}\end{array}$ & $\begin{array}{l}4-39 \\
61\end{array}$ \\
\hline 22 & $43^{\circ} 00$ & $180^{\circ} 00$ & $"$ & $"$ & $2018-23$ & 0 & 15 & - & $8-15$ \\
\hline 22 & $"$ & $"$ & $"$ & 8 & 0530 & $0-25$ & 1 & $\sigma^{3}$ & 59 \\
\hline 23 & $43^{\circ} 57$ & $177^{\circ} 30$ & $"$ & $"$ & $1621-26$ & 0 & 2 & $0^{2} 2$ & 15,18 \\
\hline
\end{tabular}

* Height $\times$ diameter is given on these coiled specimens.

\section{Ecological Account}

1 An aspect of larval history:

The male copulatory organ of $C$. cristata is situated on the right side of the trunk just below the visceral-nucleus. As was illustrated by Tesch (1906, pl. 9, fig. 34), the penis recurves a little, have the seminal groove and is accompanied with "Haftapparat" on its side. The female genital pore is a tiny opening adjoining to the anus (Text-fig. 8). In spite of the existance of such copulatory structures, no one has ever observed the copulatory behaviour of Carinarias. BonNevie (1920) found that Carinaria lamarcki challengeri posseses a "clasper" which is a darkly pigmented organ on the postero-ventral side of the animal, but it is hardly possible that the animal may "clasp" the mate with this organ.

Few informations have been available on the larval shells of Carinarias. Recently, however, FraNC (1949) described living larval specimens of various heteropods including $C$. "mediterranea" whose veliger is remarkable in having a 
very extensive velum as is seen in the reproduction of his figure (Text-fig. 23). He showed also that $C$. "mediterranea" is provided with eyes having the characteristic triangular base, this feature was observed on the specimens collected by the $R$. V. Tenyô-Maru, too.

Next, a young specimen of $C$. japonica found coiled in about $1.4 \mathrm{~mm}$ diameter and with $0.75 \mathrm{~mm}$ height is described :

Shell of right-handed, helicinoid, very thin, transparent, entirely yellowish in color, polished and entirely with extremely fine growth lines; whorls $3 \frac{1}{2}-3 \frac{2}{3}$; spire rapidly increasing diameter to the aperture; the lower part of body-

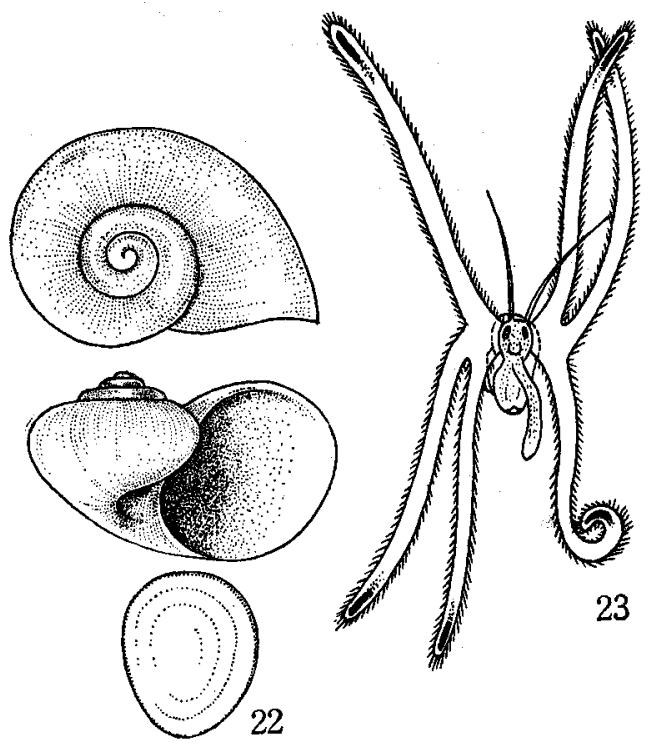

Text-figure 22. Larval shell and operculum of $C$. japonica from St. 20 of the Tenyomaru, collected on Aug. 6, 1955.

Text-figure 23. Veliger of $C$. "mediterranea" from the Mediterranen Sea (after FraNC, 1949).

whorly more inflated than the upper; operture ovate; umbilicus narrow but distinct; operculum as large as aperture, horny with a few concentric lines, transparent; animal can be wholly withdrawn inside the shell (Text-fig. 22). This structure of the shell agrees well with that of the protoconch preserved at the tip of the adult sgell. Slight inclination of the protoconch is responsible for the oblique appearance of the aperture lips in the coiling stage. Shell metamorphoses to a capuliform one with developmental stages. The boundary between the coiled and capuliform parts is quite distinct. . In a stage with $\mathrm{sH} 1.8 \mathrm{~mm}$ and sD $2.3 \mathrm{~mm}$, there are only 4 transverse ribs on the shell and the keel is $0.8 \mathrm{~mm}$ 
wide; the animal then attains $14.5 \mathrm{~mm}$ in $\mathrm{L}$ and yet the triangular tailcrest is differentiated already (Text-fig. 13).

\section{Feeding habit:}

Tesch (1949, pp. 50-51) found that fragments of Ctenophores, Salpae and pelagic Hyperiidae, such as Phronima, were spread upon the radula hooks of heteropods or remained in the gizzard. There were reportedly found mostly unidentifiable detritus, but sometimes fragments of Euphausids and even of other heteropods. He also guessed that the fish larvae might often be preyed by rapacious Carinarias and Pterotracheas. GRAHAM (1955) stated that Carinaria feeds on fish, scyphozoan medusae and crustaceans. And it must be necessary to introduce here that Carinaria is regarded as a predator of the eggs of a sardine, Sardinops ocellata (Fish. BIOL. BR., FAO, 1959).

Of the present material, two samples of food contents in the alimentary canal were examined. These contents were offered to Mr. K. Honjo of our Laboratory who identified them so kindly for the writer. Here the writer wants to express his hearty thanks for Mr. Honjo's kind help.

(i) Food contents of a $44 \mathrm{~mm}$ long female Carinaria japonica from St. 13 of the Tenyô-Maru

$\begin{array}{lc}\text { Euphausid larvae } & 6 \\ \text { Paracalanus parvus } & 1 \\ \text { Calanus sp. } & 1 \\ \text { Oithona pulmifera } & 1 \\ \text { Amphipoda juvenile } & 1 \\ \text { Evadne } \text { sp. } & 1 \\ \text { Sagitta bedoti } & 1 \\ \text { Thalassiothrix longissima } & \text { plenty }\end{array}$

(ii) The same of a $17 \mathrm{~mm}$ individual from St. 12 of the Tenyô-Maru

$\begin{array}{lc}\text { Euphausid larvae } & 1 \\ \text { Crustacean remains } & \text { many }\end{array}$

The above mentioned results seem to show that Carinarias feed on the plankton organisms in situ. Here it is very questionable that Carinarias take diatoms as food, although the alimentary canal of Carinarias contains some diatoms occurring in the same area. Rather it is impossible that Carinarias can take diatoms with radula, most probably these vegetable substances are brought in with salps which apparently feed on diatoms and then are preyed by heteropods. The fact that heteropods are occasionally collected together with a large number of Salps were already noted by DaLEs (1952, p. 1013).

Carinaria has very acute radulae, the formula of which is given in Chapter II (p. 88). Every tooth is sharply pointed at the tip (Text-fig. 24) and sickle shaped marginals are very effective to hook preys and usually peeping out of 
the mouth. One of the radular ribbons examined during the present study was found provided with 60 rows of radulae. The present author observed once on board the R. V. Sôy-Maru that the animal occassionally extended the proboscis straightly and some food particles jiggling in the gizzard were distinctly observable through the cutis.

The coloration of the gizzard and oesophagus of living animals is apparently caused by food organisms. Some examples of colorations of living Carinarias observed during this study are as follows:

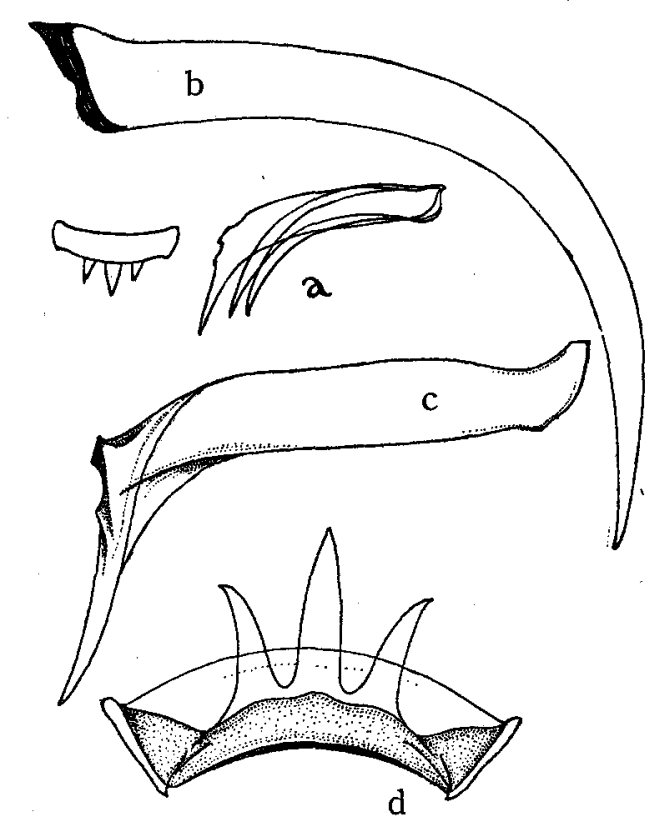

Text-figure 24. Radula teeth of C. cristata (L) of an individual from Sagami Bay.

a : half of a row, b : marginal, c: lateral, d: rhachdian.

i) Carinaria cristata from Sagami Bay: purplish.

ii) Carinaria japonica from St. 25' of the Sôyo-Maru: Orange with faintly brownish particles on the posterior part of the gizzard.

iii) Carinaria galea from St. 43 a of the Sôyo-Maru: Deep purplish red.

Yellowish coloration is caused by crustacean, while purplish coloration is probably caused by scyphomedusae, Janthina or amphipods, though this is not ascertained definitely.

3. Swimming behavior:

Living C. galea and C. japonica were observed by the present author on 
board the R. V. Sôyô-Maru in August 1958. Carinarias swam just like Pterotrachea (OKutani, 1957 c, pp. 17-19), but they kept themselves nearly always horizodtally while Pterotrachea usually keeps the body rather inclined when it is resting. The animal keeps the ventral side upwards and moves the fin as in file-fishes or puffers. In swimming the trunk winds like $S$, but the parts of the body seem hardly to contribute to locomation (Text-fig. 25).

\section{Possible predators of Carinaria:}

KING and IKEHARA (1959) reported that some heteropods were occasionally found in the stomach contents of tunas. However, It is not likely that tunas took those heteropods selectively. Although records of Carinarias being eaten by any predators are rare, it is met with very frequently that visceral nucleus

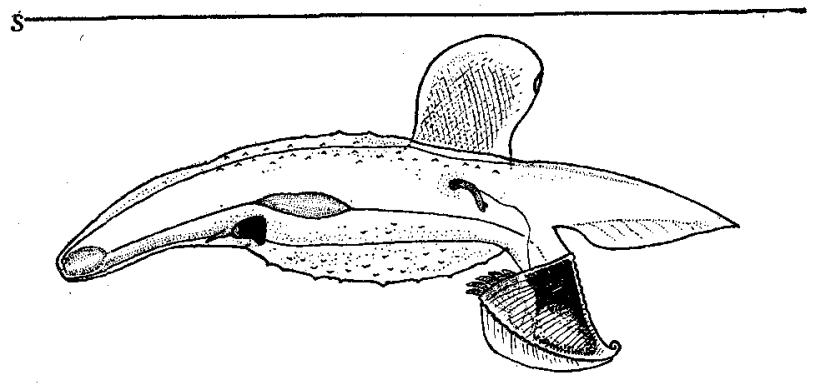

Thxt-figure 25. C. galea in natural posture observed at St. 43a of the Sôyô-Maru on Sept. 12, 1958. $s$ : water surface.

of the animal is bitten off probably by some fishes. A kind of turtle may be regarded as one of the predators of them, because some Pterotracheas have been found from the stomach of the turtle (Kurata, unpublished).

\section{REFERENCES}

Bonnevie, K. 1920. Heteropoda: Rep. Sci. Res. "Michael Sars" N. Atl. Deep. Sea Exp. 1910: $1-17,5$ pls., 10 figs.

DALES, P. 1952. The distribution of some heteropod molluscs off the Pacific coast of North America. Proc. Zool. Soc. London, 122, pt. iv : 1007-1015, 7 figs.

Fisheries BIOLOGY BRANCH, FAO 1959. Comparison of biological characteristics of sardines and related species-A preliminary note. (draft) Background paper, Subject synopsis no. 1, for World Scientific Meeting on the Biology of Sardines and Related Species, FAO, Rome.

Franc, A. 1949. Hétéropodes planktonique de Méditerrannée occidentale. Jour. Conchyl. 89 (3): 209-203, 19 figs.

Graham, A. 1955. Molluscan diet. Proc. Malc. Soc. London, 31 (3-4) : 1-6.

KING, E. J. and I. I. IkehaRA 1959. Comparative study of food of bigeye and yellowfin tuna in the Central Pacific, Fish. Bull. 108, Vol, 57.

KurodA, T. and T. HABE 1952. Check list and bibliography of the recent marine mollusca of Japan. 210 pp., 1 map., Tokyo. 
Okutani, T. 1955a. On a new species of Carinaria japonica. Venus: Jap. Jour. Mal. 18 (4): 251-258, 4 figs. 1955b. A brief note on Carinaria cristata (L.). Yamehamaguri (mimeographed journal with limited circulation) $80: 13-15$. 1957a. Holoplanktonic gastropoda in the "Kuroshio" area, south of Honshu, May 1955. Rec. Oceanogr. Wks. Japan, Sp. Num. (New Ser.) : 134-142, 3 figs.

1957b. Planktonic gastropoda; in: A preliminary report on the biological survey in the "Kuroshio" area, south of Honshu, June-July 1955, by Z. Nakai and collaborators. Rec. Oceanogr. Wks. Japan Sp. Num. (New Ser.) : 179-181, 2 figs.

1957c. On pterotrachean fauna in Japanese waters. Bull. Tokai Reg. Fisch. Res. Lab., 16 : 15-21, 3 pls., 1 fig.

Pelseneer, P. 1906. Mollusca; in: Treatise on Zoology, pt. v: 355 pp., 301 figs., London.

ReEve, L. A. 1865. Carinaria: Conch. Icon., 1 pl.

Schiemenz, P. 1911. Die Heteropoden der Plankton-Expedition: 1-13, 1 pl.

Smith, E. A. 1888. Report on the Heteropoda collected by the H. M. S. Challenger during the years 1873-1876 : Sci. Res. Voy. Challenger; Zool., Vol. 23.

TAKI, I. 1954. An illustrated handbook of shells in natural colors, 134, pl., 124 pp., Tokyo.

Tesch, J. J. 1906. Die Heteropoden der Siboga-Expedition : 112 pp., 14 pls.

1949. Heteropoda, Dana Rep. $34: 53$ pp., 5 pls.

THIELE, J. 1929. Handbuch der systematischen Weichtierkunde, Erst Teil, 376 pp., 470 figs.

TokıokA, T. 1951. Carinaria cristata (L.) ; in : Illurtrated Encyclopedia of the fauna of Japan, rev. ed. iv, Tokyo.

1955. Shells of Atlantidae (Heteropoda) collected by the Sôyô-Maru in the southern waters of Japan. Publ. Seto Mar. Biol. Lab. 4 (2-3) : 237-250, 10 figs., 2 pl.

VAYSSIÈRE, A. 1904. Mollusque hétéropodes: Albert 1er Prince de Monaco, Camp. Sci. $26: 61$ pp., 6 pls.

Woodward, S. P. 1890. Manual of the mollusca, iv ed. 


\section{EXPLANATION OF PLATES XII-XIII}

\section{Plate XII}

Figure 1. Carinaria cristata (L.); a $240 \mathrm{~mm}$ long male from Kasajima, Sagami Bay, collected by NaKamigawa, coll. 3907.

2-3. Carinaria cristata (L.); Shell of an individual from Tosa Bay, $\mathrm{sH}=22.6 \mathrm{~mm}$ (leg. Teramachi).

4. Carinaria cristata (L.) ; Darkly colored $340 \mathrm{~mm}$ long injured female from Niijima Isl. (Mr. Y. KuRATA photo).

\section{Plate XIII}

Figure 1. C. cristata (L), the same specimen with that shown in Pl. XII fig. 1.

$\mathrm{a}:$ anus, $\mathrm{c}$ : ctenidia, $\mathrm{d}$ : vas deferens, $\mathrm{g}:$ male gonad, $\mathbf{k}:$ kidney, $1:$ liver, $\mathrm{t}$ : atrium of the heart $\mathrm{v}$ : ventricle of the heart.

2. C. japonica OKUTANI, type specimen, $62 \mathrm{~mm}$. long female.

3. C. lamarcki Péron et Lesueur; a $25 \mathrm{~mm}$ long female from the station $30^{\circ} 38.9^{\prime} \mathrm{N}, 131^{\circ} 23.8^{\prime} \mathrm{E}$. (Mr. NAKAI orig.)

4. C. galea BENSON; a $21 \mathrm{~mm}$. long female from the station $30^{\circ} 49.3^{\prime} \mathrm{N}, 140^{\circ} 48.3^{\prime} \mathrm{E}$.

5. C. galea BENSON; shell of a male from the station $35^{\circ} 25^{\prime} \mathrm{N}$, $142^{\circ} 29^{\prime} \mathrm{E}, \mathrm{sH}=11.2 \mathrm{~mm}$.

6a-b. C. lamarcki Péron et Lesueur; shell of an individual from the station $32^{\circ} 46.3^{\prime} \mathrm{N}, 133^{\circ} 08.8^{\prime} \mathrm{E}, \mathrm{sH}=3 \mathrm{~mm}$.

7. C. japonica OKUTANI, shell of an individual from the station $43^{\circ} \mathrm{N}, 162^{\circ} \mathrm{E}, \mathrm{sH}=5 \mathrm{~mm}$.

8. C. lamarcki challengeri BoNNEviE; a $15 \mathrm{~mm}$ long female from the station $34^{\circ} 18^{\prime} \mathrm{N}, 140^{\circ} 56^{\prime} \mathrm{E}$. 

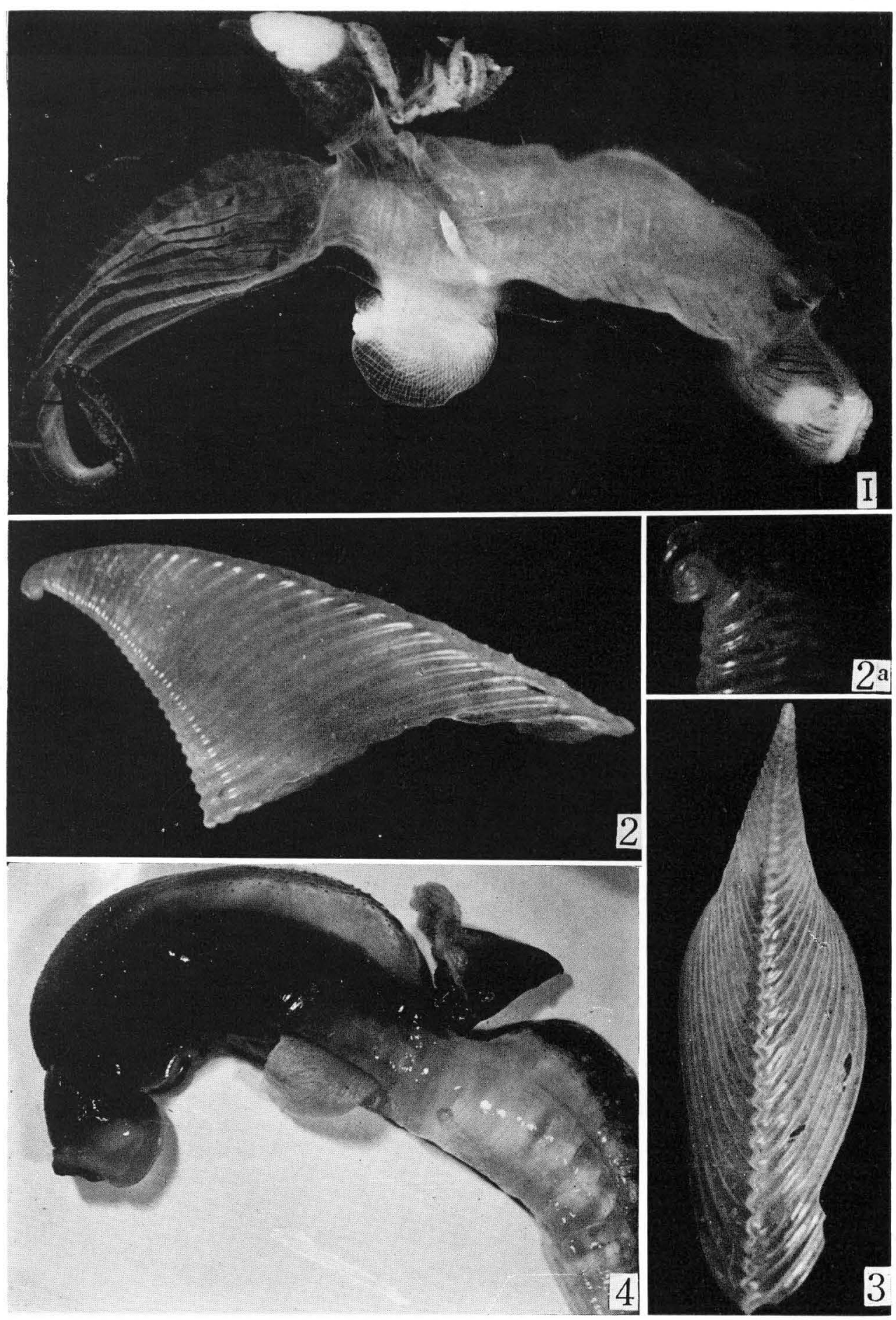

T. Okutani; Notes on the Genus Carinaria (Heteropoda). 
Publ. Seto Mar. Biol. Lab., IX, 2 (1961.)

PLATE XIII
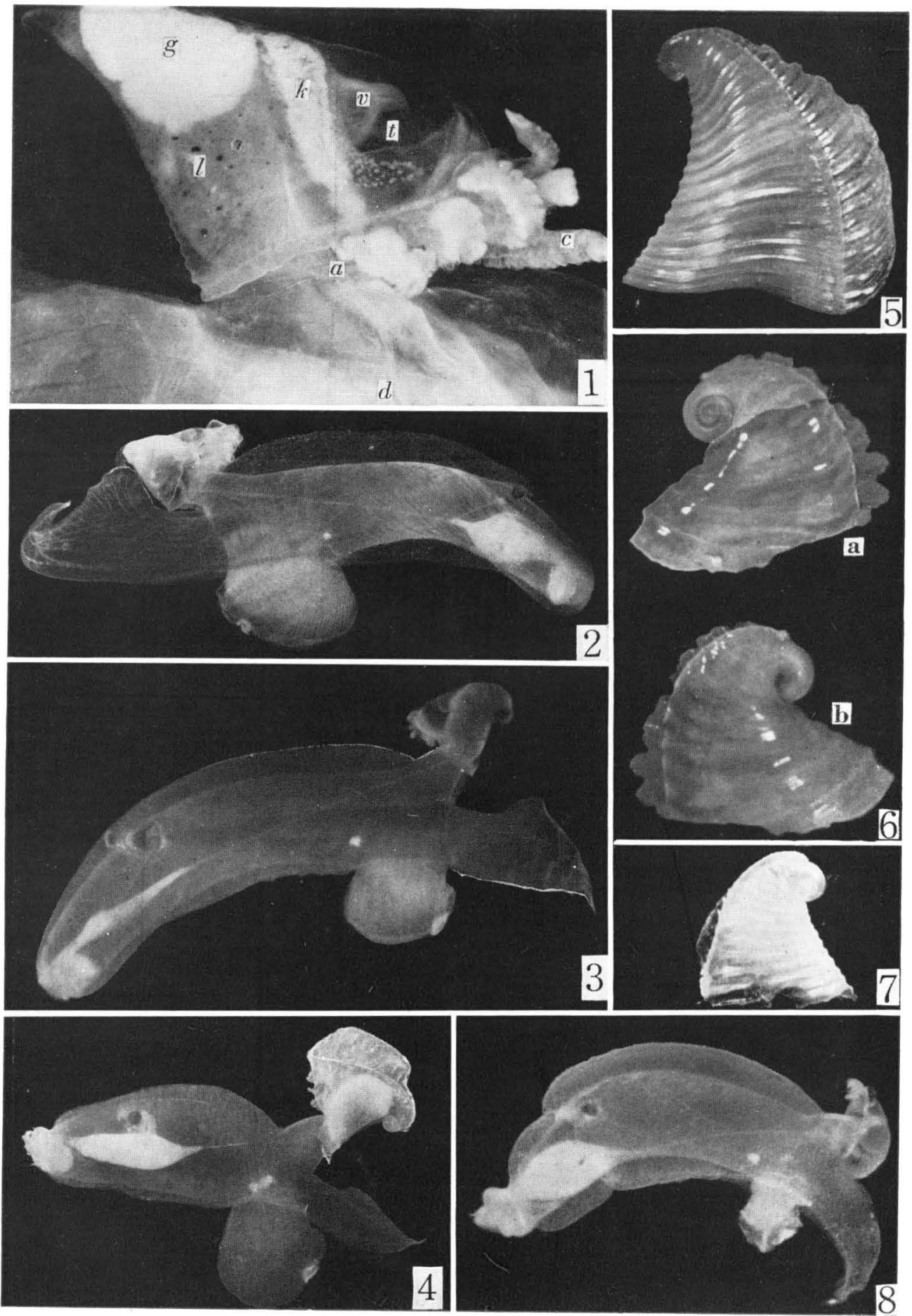

T. Okutani: Notes on the Genus Carinaria (Heteropoda), 